\title{
Moral Equivalents of Greed
}

\author{
Alan Cottey \\ University of East Anglia, Norwich NR4 7TJ, UK \\ e-mail: a.cottey@uea.ac.uk
}

\begin{abstract}
The author considers William James' 1910 essay The Moral Equivalent of War and applies some of its ideas to another pressing problem of our times, which for short is called greed but can be described more precisely as the working out of the possessive market society under the conditions of neo-liberalism and great technological power. James considered that pacifists had the best arguments but failed to persuade mainstream society. The same can be said today of the critics of neo-liberalism. There is need for radical change away from an unjust and dysfunctional economic system but mainstream society is unwilling to try new ideas. The present author adapts James' idea and considers benign and malign forms of greed. What we all desire, more than huge monetary assets, is self-respect and social respect. There are already many rewards that are not primarily monetary. In a radically different culture, which rejected the principles of unlimited accumulation and almost unlimited convertibility, benign rewards would motivate constructive activity. The moral equivalents of greed briefly discussed here are - Honours and prizes for merit (administered justly); Celebrity (important in society); Luck (gambling, with certain constraints, could be benign); Power (rewarding in itself, so large monetary gain need not go with it); Services (people making important contributions to society could concentrate their commitment); Temporary custody of public treasures (a privilege prized by some). The essay ends by linking James' idea, the Faustian bargain myth, and the necessity of hope.
\end{abstract}

Keywords Moral; War; Greed; Sustainability; Economics

\section{The continuing relevance of William James' The Moral Equivalent of War}

William James' The Moral Equivalent of War, presented as an address (James 1906) and in 1910 published as an essay (Burkhardt 1982), elicits an enduring fascination, almost as much for its defects as its virtues. James recognised complexity and valued ambiguity, contradiction and paradox. Some of this might well be guessed by anyone coming for the first time across this title. On reading the essay, furthermore, one quickly becomes aware that James, although an ardent pacifist, admired certain military virtues and he was very serious about this and not by any means ironic. His main purpose was to emphasise that though the rational case for pacifism is extremely strong, the case seems not to be heard by many. While many things concerning war and related violent organised acts have changed during the subsequent century, this basic point remains as valid and relevant as it was then, hence the continuing interest in the essay; see for example Roland (no date). Indeed, humanity's failure to progress far with the programme of rendering war an obsolete, culturally unacceptable, institution shows more clearly than ever the need to attend to James' implied question - why? One of the principal differences between James' time and now is that almost every educated person is aware in some sense that our human culture is now problematic in a broader way than the acceptance of the institution of war; broader than the mere (!) existence of military arsenals capable of destroying civilisation and much more besides; broader than our will to build these things; broader than our willingness to use them in an omnicidal act 
(even if, admittedly, such an act has not occurred during the approximately sixty years that it has been possible). We now recognise an interlinked range of planet-wide self-destructive practices which are leading to a "perfect storm" (Beddington 2009; see also Edwards et al 2006). This broader problematic may be summarised by some such general phrase as 'planetary ecological crisis'. In this article I will for the most part leave aside the many environment dimensions of this crisis and attend to economic aspects, which have received much academic and popular public comment in recent years; see for example Battersby et al 2012, Collins 2012, Frangioni 2012, Larrea 2011, Murphy 2011. Those who think about this serious situation, already bad enough and likely to become catastrophic, are in a situation similar to that of those, of today, during the Cold War era, and in James' time, who see the barbaric character of war and are bemused at the lack of purchase that their arguments have upon public opinion.

In writing an article about current economic injustice and drawing a parallel with James' essay, I will not enter into a critique of The Moral Equivalent of War but I must, to forestall misunderstanding, comment briefly on the differences between that essay and the present piece. In my opinion, James' title, while being an inspired 'come-on', is misleading in referring to The moral... From a reading of the entire essay, it appears that James is interested in finding a range of activities which will satisfy humans' thirst for excitement and their need for discipline without resorting to the barbaric institution of war. I believe this to be a correct interpretation even though James discusses, at the end of the essay, only one example, and a rather narrow one at that, namely a period of universal conscription for male youths, to harden them and give them a sense of civic duty. Following an impressively gory account of war through history, James' essay ends rather cursorily and superficially, perhaps because it started life as an address (James 1906) and the speaker ran out of time. I have dropped The from my title and offer a multiplicity of 'benign rewards' that, in a suitably reformed culture, would replace the current fixation on monetary reward. Another clarification I will make at this stage concerns the words War and Greed. In James' day, war was, or seemed, less complicated. Today, the term is used in many ways. Sometimes states, and those who accept the language, avoid the simple term and refer to qualified terms, like guerilla war, or other terms, such as conflict. And it is indeed true that violent hostilities, organised to a greater or lesser extent, conducted on a greater or lesser scale, subject to more or fewer restraints, comprise a complex array of activities. Further, the use of the term war can be an obfuscation, often introduced as spin. Terms like the war on terror and the war on drugs are of this kind.

Likewise the word Greed in the title of this article requires clarification. It is a shorthand for a mindset, developed over millennia and intensified in the centuries of capitalism, which associates an individual's personal worth with the monetary value of their private assets (property, in the general sense) and not with their self respect and respect in society. Greed is a pejorative term but I hope that the use of the word in this article will be accepted as a way of connecting with the most valuable of James' ideas and building on them. One of these is that if pacifists are to gain purchase for their ideas with "the war-party" (pages 165 and 170 of Burkhardt 1982) it is necessary to engage in dialogue with those who think militarism necessary and war unavoidable. (The term war-party sounds unhelpful to our ears but is used respectfully by James because he has great respect for certain aspects of the military life.) Likewise, I want to engage with the majority view of the present times and understand why we are hell-bent on our headlong collision with nature - the evocative subtitle of the book by Edwards, Timberlake and Dylan (2006). Why is enough never enough? James was multi-talented but primarily known as a psychologist and his answers to the why questions about war have an 'innate psychology' tendency

"modern man inherits all the innate pugnacity and all the love of glory of his ancestors. 
Showing war's irrationality and horror is of no effect on him. The horrors make the fascination."

James 1910 p163

I will take a more socialist and historical approach (James came from and remained in an elite intellectual milieu and, for a pacifist, had a distinctly conservative point of view). This shows in another difference between James view and that taken in the present article. Empathy is a word that, in James time, was newly introduced into English, as a translation of the German Einfuehlung. The first of the Oxford English Dictionary's numerous quotations is from 1904 and the meaning given is "(Psychology and Aesthetics) the power of projecting one's personality into (and so fully comprehending) the object of contemplation." James does not use the word in his essay but he was fluent in German and evidently concerned with the concept. He writes

"Pacifists ought to enter more deeply into the esthetic and ethical point of view of their opponents."

James 1910 p168

Since those times, the usage of empathy has shifted and the aesthetic aspect is rarely intended. The Oxford Dictionary of English (Soanes and Stevenson 2003) gives "the ability to understand and share the feelings of another". I also find useful the concise expression given on p91 of Rosenberg (2005) - "a respectful understanding of what others are experiencing." I aim to apply these ideas in the following discussion of greed and of our current cultural emphasis on measuring personal worth in monetary terms.

\section{Possessive Individualism and Greed}

Just as James devoted an early part of his essay to a reminder of the bloodiness and ubiquity of war, so I will review briefly the hold of acquisitiveness on the human imagination and how it has developed over the recent millennia (probably longer but then we would be entering into ideas in archaeology that are plausible but more speculative) and centuries. On the millennia timescale, the developments of agriculture and of writing are central (Korten 2006). Together they made possible the development of imperialism. Agriculture made surpluses possible and writing allowed large scale organisation so that the surpluses could be used. Large scale societies were, and still are, strongly hierarchical. It is worth noting, what many in the public and the mass media do not know or else overlook or regard as insignificant, that the modern meaning of hierarchy has developed gradually over millennia from origins involving priestly government. Even though overt power was wielded by kings and emperors, that power was made possible by a priestly class, who were literate and mediated the control of resources and minds. In these circumstances, resources and power become concentrated. In other words, accumulation occurs.

Passing thus swiftly over millennia of great empires and considering recent centuries, we come to the era of capitalism, starting with the rise of fractional reserve banking, which decisively changed the balance of economics from gain by way of production to gain by way of capital (see for example Engler 1995). There followed somewhat later a rapid increase in scientific knowledge and technical advancement. Then the age-old human struggle to gain the basic necessities of life, in other words, conditions of scarcity, could in principle come to an end. Under new conditions of abundance, there would no longer be need for cruel exploitation. This was expected by Enlightenment thinkers. It is usual nowadays to notice that their ideas were not quickly realised but 
not to recognise that some of their expectations have come to pass, albeit often in an unexpected way. In particular, we now live in an era when the global economy, so far from requiring nearly everyone to produce, harvest and use resources laboriously and thoughtfully, apparently requires of all an exhausting struggle to maintain economic growth, since it is thought by those in power and by those whose ideas are formed by the mass media (see, for example Medialens, no date), that 'there is no alternative'. It is feared that if growth were to stop, the entire edifice of current trading (and it is almost entirely for capital gain with only a small fraction being trade in goods performed for use value) would collapse. For a US critique of the ideology of growth, see also Eight Fallacies about Growth (Daly, no date). How did 'progress' go so terribly wrong?

\subsection{Possessive individualism}

Two concepts which I find especially helpful in trying to understand the bind into which we have placed ourselves, are possessive individualism and possessive market society. Many years after the publication of C B Macpherson's The Political Theory of Possessive Individualism (1962), that author's ideas, long rejected as being falsified by the rise of neoliberalism, are attracting more interest. See, for example, Duchrow and Hinkelammert (2004) and Rifkin (2000). Macpherson places the concept of private property at the centre of his interpretation of contemporary politics and its history since the 17th century. In Macpherson's analysis, John Locke is especially important. He is represented as philosophically inconsistent but highly influential because he constructed a theory which was convenient for the rising bourgeoisie in that it gave out a comforting message of equality (thus justifying the spread of power beyond the confines of the established aristocracy) while, in a disguised manner, excluding those without property from the ranks of civilised humanity. Locke's writings, especially the Second Treatise of Government (Locke, 1690), have been an important plank supporting liberalism ever since. The main challenger, socialism (in some form or another) was a rising rival through most of the nineteenth century and the first two-thirds of the twentieth. Around this time the opinion of liberals that socialism necessarily took a totalitarian form became more widespread, leading to the gradual political and economic dominance of neo-liberalism. Macpherson's take on the centrality of property, while frequently criticised at first has now become better appreciated, as the unjust and dysfunctional nature of neo-liberalism has become more obvious. My very brief summary of Macpherson's take runs thus - Property and contract are inviolable, almost sacred, and in practice often take precedence over any human being's basic needs. Property, including a person's labour, can be bought and sold and the price is determined by a 'free' market, where free includes the freedom of the stronger party to exact advantageous terms with few restraints. Finally, the term possessive market society is used, rather than possessive market economy, to indicate that "market relations ... permeate all social relations" (p 48 of Macpherson 1962).

\subsection{Greed}

In today's dominant global culture the worth of a person or an institution or an activity is often represented in monetary terms. The wide reporting of and public fascination with the annual Forbes' (no date) The World's Billionaires, informally known as the Forbes Rich List, is but one of many attestations to this. These 'worths' are also referred to by Forbes and by commentary as 'fortunes', a usage that indeed is time-hallowed. Nevertheless, the unthinking assumption that 'worth' and 'fortune' are monetary quantities, or have monetary equivalents, is part of the general problem. It turns people's minds towards all that can be measured in monetary terms and away from 
connections with wealth in the senses well, weal, commonweal, hale, heal, health, whole or with fortune in the senses of fortunate, lucky, blessed, favoured, happy. Those monetary fortunes are gigantic and increasing. Meanwhile, at the other end of the spectrum, the life of the disadvantaged is becoming worse than it was several decades ago (see, for example, Collins 2012). This extreme and increasing inequality (Battersby et al 2012) and injustice occurs in all nations. A global economic melt-down is a real possibility but the current response is not to curb the excesses but rather to scapegoat the disadvantaged (Lagman 2009).

Money, in the gigantic amounts now accumulated by the 'richest' individuals has a symbolic character (Rowe 1997). Bankers and CEOs, who have for some years been castigated by the media, especially when board and trust members award each other huge bonuses for having taken risks that fall apart, are driven by a pervasive culture of unending competition (Brown 2002). If Bloggs has a bonus of 15 millions this year, Blaggs is gutted if he (and it usually but not always is 'he') cannot get a bigger bonus. Meanwhile the general spread of affluence translates into mass consumerism Barber (2008), with disastrous effects on the world's ecology (Kempf 2008).

\section{Culture and technology}

Greed, or to speak more neutrally, a commitment to possessive individualism and unlimited accumulation, is not confined to a fixation on money or its more obvious conversions. There is also an ideological commitment to the possessive market society. For an example of the malign effects of this on academic medicine and patient care in the USA, see Frangioni 2012.

\subsection{Culture}

Human energy and talent is often expressed in ways which are creative but which, in the ethos which has developed (Korten 2006) over millennia, have destructive as well as constructive aspects. History is full of alpha-males, and some alpha-females, who have contributed to civilisation; sometimes the destructive aspects are considered a price worth paying for great constructive achievements and in other cases the constructive aspects of a psychotic person's talent are a small corrective to an overwhelmingly negative legacy. Someone's personality may also change as a result of great achievement. Robertson (2012) declares (p28) that "an increase in egocentricity and a reduction in empathy" occurs in individuals holding great power. He also maintains that this connection has a neurological basis that is now understood.

\subsection{Technology and the new Faustian bargain}

Human ingenuity has developed many marvellous technologies. Some of the more important of these may be labelled, in a simplified representation - agriculture, writing, mechanical mass production (the first Industrial Revolution), digital information processing (Information Technology), gene processing (Biotechnology). Each has transformed, or is transforming, human life - what it is to be human. The first Industrial Revolution is remote enough for us to be able to see the historical course it took. The others mentioned are much more remote (so that only a very rough outline of what happened is known) or recent and ongoing (so that we have as yet an incomplete 
understanding of what is happening). In the early stages of the first Industrial Revolution the new possibilities were exploited by the owners of capital with a ruthless disregard for the welfare of those who owned no property. See, for example pp8-10 of Engler (1995). The extreme inhumanity is, to many modern minds, if they learn and think about it, sickening. The conditions in England gradually became known and ameliorated, although only as a result of prolonged struggles by the oppressed themselves, by socialists and by relatively philanthropic liberals, in the teeth of powerful opposition. Thus mechanical mass production, which could (from a solely technical point of view) have ended humankind's long ages of scarcity, did no such thing (Easlea 1973), but rather contributed to economic growth that took the form of gross inequality ameliorated by grudging redistribution.

We cannot say how the IT and biotechnology revolutions will appear, a couple of centuries hence. But we do already know that the new possibilities could, again from a solely technical point of view, go beyond simply ending scarcity. They could make possible a creative life for all people, with machines and computers doing most of the heavy and repetitive work, freeing humans for selfand social- development. Here indeed is a place for growth. Yet it appears already that the amorality of the early stages of the first Industrial Revolution is reflected in the manner of exploitation of the new technologies. It is not simply that the technologies are being exploited amorally. The speed of development of powerful applications, notably IT and biotechnology, far outstrip the rate at which civilised customary norms and formal laws are developed. The bad conditions are hidden from all those who do not make an effort to be aware. A large fraction, some billions, of the whole world's population are materially prosperous. This, in itself, is something to be celebrated. Yet it comes at an enormous price. Everyone who accepts the material prosperity and puts off thinking about the price has made the Faustian bargain - gratification now and for a limited period but an intolerable and unavoidable bill coming later. The gift allows the Faust character to achieve all his desires, noble and ignoble. (For a detailed history of the enduring Faust legend, up to present times, see Durrani 2004.) Modern technology can seem, to some, to offer everything. It is easy to be seduced, especially as capitalism needs continual growth and uses control of the social environment to titillate our appetites and to discourage critical thought about the eventual reckoning. An example from IT of one of those great gifts is the enormously rapid increase over a short period of time of internet connection bandwidth at low cost. Yet the appetite of ourselves and of capitalism quickly increases until we want more (Hecht 2012). Enough is never enough.

The development of law and social practice is even worse than indicated above, where I mentioned its lag. Patent law, in particular, has accelerated the concentration of power into the hands of a decreasing number of plutocratic corporations and individuals. The word plutocratic which is often used in a polemical and hostile manner, is here used more advisedly and literally, because these plutocrats do indeed govern (Korten 2001). This they do by bank-rolling the major political parties and the candidates for major political office. Now, in supposedly democratic countries, elections offer a choice between two options with merely cosmetic differences. Thus has the phrase sham democracy become more widely used in recent times and it is not a mere expression of cynicism but rather an accurate description of the current situation (Vox 2010).

IT is especially implicated in the concentration of power through its ubiquity in stock exchanges and banking. Global trades are now almost wholly speculative, for the purpose of capital gain, with only a small fraction being for the promotion of common human needs and improvements. These speculative trades rely on minute fractional advantages gained at the centre. They are gained by using sophisticated mathematical forecasts of market changes, on huge transfers, with even 
milliseconds carrying a speed advantage. The ensuing 'gains' go on all the time and pay little or no tax. Meanwhile, devastating but apparently irresistible consequences fall on people at the margin, who were already struggling to survive with dignity.

\subsection{The world we create}

This sub-section is a preliminary to section 4, Satisfying the Moral Equivalents of Greed with Benign Rewards. It argues that such an idea is realistic, even though most people see the future as a projection of the present. The composer Edgard Varèse is quoted (Salter 1962) as having put it more strongly "Contrary to general belief, an artist is never ahead of his time but most people are far behind theirs." We are living in unstable times, economically and ecologically. If we do not create visions of how to escape our self-imposed chains, our relations with each other and with the natural world will further deteriorate and our civilisation will be lost and not recover for a long time. Like James in respect of war, I do not think that greed (or strong desire) can be simply abolished. But moral equivalents, or substitutes, are readily to hand and widely used already. I will discuss several examples in the next section. First, we must find a social context in which such substitutes would satisfy. The first step is to divide our desires into those that are malign and those that are benign. There is nothing new about doing this. All peoples have sets of deeply held common values. They say this is good and acceptable, that is bad and unacceptable. We are now at an historic crisis point, a decision point. We have to say

all actions that threaten the social and natural fabric of planet earth are unacceptable. They must be rendered off-limits. It is not a matter of empty talk, nor a matter of timid ameliorations of present conditions. It is a matter of bringing to an end the long era of treating other people and the Earth as resources to be exploited. It is a matter of living together with each other and the rest of the living and inorganic parts of this planet.

This is a tall order and, as with William James about war, I am interested in finding those moral equivalents which might help to make possible the Great Turning (p6 of Macy and Brown 1998; Korten 2006; Johnstone, no date). The discussion of moral equivalents in the present article is intended to contribute, and encourage other contributions, to constructive engagement with conservatives, reactionaries (I use this as a literal and not necessarily pejorative term), climate skeptics and, perhaps especially, those who believe in business-as-usual. See Hulme 2009 for a thoughtful attempt at engagement in the case of the climate change controversy.

\subsubsection{Three visions}

In this article I will not present a blueprint of any particular world transcending the current form of greed, based as it is on the possessive market society. Nevertheless, it will be helpful to outline briefly a few examples of the kind of visionary thinking that is appropriate for our times, examples that I consider not at all 'way out' in view of the radical social and ecological changes that are already afoot and accelerating...

Maximum assets and income: If we consider in an empowered way, and not in a disempowered, whinging way, the enormous incomes received, and accumulations amassed, by many individuals, often gained through useless or harmful activities, we may conclude that it is simply common sense 
to consider what schemes of limitation are practical and desirable. A proposal for a workable scheme, involving personal and holding (in escrow) accounts is described in (Cottey, no date). Another approach is taken by Larrea (2011) who proposes a greed line, defined as "the maximum ethically acceptable individual consumption in the current global economy." By 'line', Larrea means that the maximum is a function of various circumstances. Maximum income is also discussed in the extensive treatise Greed and Good by Sam Pizzigati (2004).

Basic income: In a post capitalist era, basic income (known also by numerous other names, including universal income, citizen's allowance, national dividend; for examples, see Raventós 2007, Roberts 1982, Walter 1989) will be entirely feasible. Basic income is an allowance paid by the state (or some similarly capable social entity) to each of its members as individuals and is sufficient to permit a simple but dignified living. The allowance is paid directly to all competent persons and to a guardian for those, such as young children or the demented, who lack an elementary competence in managing their own affairs. The allowance is paid to all, irrespective of any other income they may receive. Most people in a given society will receive the same amount but variations may apply to special categories, such as children and the elderly. The allowance is such that most people will feel the incentive to gain extra income, through employment, but there will be no pressure on those who live by choice on the basic income.

Definition of Work: This word 'work' is one of the most mis-used in the language. Contemporary discourse uses the word with many assumptions which, in this discussion, I wish to avoid. In a postcapitalist world heavy labour and repetitive labour could be done largely by physical machines and software. Moreover, a significant element of 'work' as currently understood comprises activities undertaken either to control people's lives or to maintain a semblance of 'full employment' (Roberts 1982). Quite apart from the inhumanity of denying a living to those who cannot find profitable employment, or offering basic support grudgingly, the present economic culture is dysfunctional because it assumes than rapid capital growth is necessary. Technology has made possible a world in which basic income is easily affordable, paid for by taxation of that great majority who choose to augment their basic income, or by sales taxes, or by a combination of these. It is also possible, in a more rational economic system to share work, so that the norm involves a small amount of profitable work. The real job of humanity is to think through and implement ways of using constructively the enormous benefits of the inventions of the last few millennia. Humanity's remarkable energy and creativity could be freed up for this heroic task.

\subsubsection{The need for moral equivalents of greed}

William James considered that certain virtues associated with the military mind-set should be harnessed to constructive ends. I consider that James' specific proposal, conscription of male youths into hard labour, is unsatisfactory. And so is his motivation, which has a patrician character and is excessively focused on hardihood. Yet his basic idea, that of directing human energy to constructive ends, is sound. Now, in the 21st century, it is worth considering whether merely disapproving of greed (using this term as shorthand for a mindset that associates an individual's personal worth with the monetary value of their private assets) and pillorying selected individuals is going to get us anywhere useful. So far it has not. 'Wealth' as generally understood - that is, sum of assets convertible into money - is, in the upper range, a surrogate. What people need most is approbation and status. This need not be a problem. It is only (!) required that everyone be restrained from practices that harm other humans and the environment. These include excessive consumption, 
excessive pollution and the enclosure (privatisation) of property (in its most general sense) when that practice harms those who are excluded. On today's overloaded planet these general categories cover a great deal. Does much remain? Yes! There is plenty of scope for enjoying and extending the beauties of our world and of the positive aspects of the civilisation that we have constructed over millennia and more. The question is, how to restrain the harmful practices while encouraging the beneficial? There is nothing new in this question. Civilised customary norms, legislation and administration aim to do just that. The great problem of our times is that, under capitalism and the Lockean defence of unlimited accumulation, these efforts are like swimming through treacle.

Money is a wonderful invention. It has various roles (Douthwaite 1999) but the relevant one here is conversion. Under neo-liberal deregulation, it has become possible for the rich to convert investments from one home to another at lightning speed and at negligible cost. Laws which are intended to protect beneficial activities and restrain harmful ones are easily circumvented, largely because of the general whole-hearted commitment to freedom (for the powerful) and the halfhearted commitment to protection of vulnerable people and vulnerable nature. The solution is a drastic reigning-in of convertibility, so that beneficial activities can still be traded for each other but not for harmful activities. There can be more-or-less unlimited virement between beneficial activities but no virement between these and harmful activities.

The matter is not simple because people have to live and they need resources of various kinds, many of which, in total, push up against the planet's ecological limits. The solution must be rationing in some form. This is a concept that is unfashionable, in this possessive market society, yet it is the only way that necessary resources, like food, water, energy, shelter and health-care can be provided for all without permitting waste by those who have benefitted from the principle of unlimited accumulation.

I remarked earlier on humanity's remarkable energy and creativity. This can no longer be strongly linked to 'success' and 'freedom' in the manner that has developed during the centuries of capitalism. It must no longer be possible to convert almost any good into almost any other. Yet some people will remain hungry for, some even lust after, success in the sense of social approbation. With these remarks, I turn to some examples of benign rewards, which constitute examples of moral equivalents of greed.

\section{Satisfying the Moral Equivalents of Greed with Benign Rewards}

A sustainable world must be much more just than ours is, but it need not be strongly egalitarian. Talented, determined or lucky people might have much more glamour, or respect, or fame, or honour, or power than other people. It is essential, however, that these rewards be not convertible into harmful assets or activities. Here are some the ways in which some people could be privileged.

- Honours and Prizes for Merit: The value of these depends, of course, on their credibility as accurate measures of merit. Such honours are very numerous. They are taken seriously, despite, in some cases, a pretence to the contrary. In the arts some high profile, prestigious prizes have quite small monetary value, but are very important to those who win them, to those who would like to win them and to a wider public that likes to have heroes. English (2005) identifies an economy of cultural prestige. In innumerable specialist areas of 
expertise these prizes, etc, are very important to the community of experts. Other honours are not for specialist expertise, but for service to the community. Concerning honours of the ennoblement type - these are, and have been in the past, awarded for various reasons, by no means all associated with merit or genuine public service. Reservations about this should not obscure the major role that a fairly administered 'honours for merit and public service' system could play in a society with an asset and income limits (AIL) scheme in place.

- Celebrity: this is often regarded as a manifestation of triviality and emptiness, in the celebrities themselves and in their admirers. I suggest, on the contrary, that celebrity is important for human society and fulfils a need, namely for personalities that all of us in a society feel we know, although they are in reality distant from us. Many present in a social gathering have the celebrities in common, and can gossip about them. The celebrities are a social cement. This is important in the present era, with its specialisation of labour, mass production of goods and services, and global telecommunications. Shopping in a supermarket is an exemplar of many of our real social transactions, impersonal and impermanent. We interact like atoms in a gas. Meanwhile, the state of celebrity is highly prized. Many would like to achieve it, but the competition to become and remain one of the few that everyone knows is intense. In a society with AIL, celebrity will, I believe, continue to have a significant role. The fact that great 'wealth' is important to many of today's celebrities is merely a reflection of a general attitude in society, an attitude that can change, as the downside of AIU (assets and income unlimited) becomes apparent. Glamour, wit, eccentricity, notoriety, power and talent are easily sufficient as qualities that would-be celebrities may cultivate, and with which the rest of us may be fascinated.

- Luck: gambling attracts many people. It could continue under AIL. Huge, convertible prizes would no longer be possible, but several alternatives remain ...

- big celebrity prizes (Be Honorary Head Of State for a Day!)

- big non-convertible prizes (have a prestige seat at a big soccer stadium for a season)

- moderately large cash winnings (the winner can then reduce his or her need to work for some years)

- Power: for some, this is reward in itself. Basic income and AIL will not reduce the supply of people striving for great office

- Services: people making especially important contributions to society could be allowed to concentrate their talents and commitment. It would be quite in order for part of their reward to take the form of services which allow them not to spend much time on the routine tasks of normal everyday life. Non-convertible provision of such services as cooking, cleaning, shopping, driving and maintenance of property would be appropriate for those doing specially responsible or uniquely skilled work

- Custody of treasures: rewards such as custody of a renowned painting, or wardenship of a stately home, can be devised. Such rewards can span a wide range of 'prestige value', from modest to large. 


\section{James, Faust and hope}

William James noted that those opposed to war had good arguments but were not being heard. He did not despair, however, but instead proposed a different track - sublimation. True, the 20th century shows that neither James' nor any other kind of pacifism gained much purchase but at least we are still here. Transcending war is a long haul. Transcending neo-liberalism and greed is also a long haul.

Technology has given us enormous powers, for good or ill. This is why the Faust myth is so compelling and finds a place in the thinking behind this special issue of AI\&S. The myth has inspired countless artistic and intellectual works, covering a remarkable range (Durrani 2004), yet one factor is constant. Faust is a tragic character. His bargain moves inexorably to pay-back time, and everyone knows it. If we, now, in our dire ecological and moral predicament, take the Faust legend as reality, we must despair. And the prophecy of doom will be self-fulfilling. We must remember that the story is salutary but still a myth. We are not locked into a tragedy, which proceeds to the bitter end, the protagonists walking into it with open eyes. The present essay is intended to indicate some ways in which humanity could yet avoid the worst outcomes, albeit only by a decisive rejection of some of its currently cherished values.

Acknowledgments I acknowledge with thanks comments from T Belton, D Iseli, P Lanyon, P Le Mare, CA Mead, P Nicholls and P Pickbourne.

\section{References}

Barber B R (2008) Con\$Umed: how markets corrupt children, infantilize adults, and swallow citizens whole. Norton, New York

Battersby S, Else L, George A, Norton M I, Pearce F and Rogers D (2012) The Age of Inequality. New Scientist 215 (2875):37-45

Beddington J (2009) The perfect storm. http://www.bis.gov.uk/go-science/news/speeches/theperfect-storm accessed 11 August 2012

Brown D (2002) Insatiable is not sustainable. Praeger, London

Burkhardt F H (1982) The works of William James: essays in religion and morality. Harvard University Press, Cambridge, MA. (James' 1910 published version of The Moral Equivalent of War is on p162-173)

Collins C (2012) 99 to 1: how wealth inequality is wrecking the world and what we can do about it. Berrett-Koehler, San Francisco

Cottey A (no date) Asset and income limits. http://www.uea.ac.uk/ c013/ail/ail.html..accessed 11 August 2012

Daly H (no date) Eight fallacies about growth. http://steadystate.org/eight-fallacies-about-growth/ accessed 11 August 2012

Douthwaite R (1999) The ecology of money. Green Books, Totnes, UK 
Duchrow U and Hinkelammert F J (2004) Property for people, not for profit. Zed Books, New York Durrani O (2004) Faust: icon of modern culture. Helm Information Ltd, Robertsbridge, UK

Easlea B (1973) Liberation and the aims of science: an essay on obstacles to the building of a beautiful world. Chatto and Windus, London

Edwards M, Timberlake L, Dylan B (2006) Hard rain: our headlong collision with nature. Still Pictures Moving Words, London

Engler A (1995) Apostles of greed: capitalism and the myth of the individual in the market. Pluto, London

English J F (2005) The economy of prestige: prizes, awards, and the circulation of cultural value. Harvard University Press, Cambridge, Mass

Forbes (no date) The world's billionaires. Forbes. http://www.forbes.com/billionaires accessed 11 August 2012

Frangioni J V (2012) The impact of greed on academic medicine and patient care. Nature Biotechnology 26 (5):503-507

Hecht J (2012) The end of cheap internet? New Scientist 215 (2874):22

Hulme M (2009) Why we disagree about climate change: understanding controversy, inaction and opportunity. Cambridge University Press, Cambridge

James, W (1906) The moral equivalent of war.

http://en.wikisource.org/wiki/The_Moral_Equivalent_of_War accessed 11 August 2012

James, W (1910). See Burkhardt 1982

Johnstone C (no date) Great turning times. http://greatturningtimes.org accessed 11 October 2012

Kempf H (2008) How the rich are destroying the earth. Green Books, Totnes, UK

Korten D (2001) When corporations rule the world, 2nd edition. Berrett-Koehler, San Francisco

Korten D (2006) The great turning: from empire to earth community. Berrett-Koehler, San Francisco

Lagman J F (2009) The poor, scapegoat for the greed of a few. Philippine Online Chronicles http://www.thepoc.net/poc-presents/parokya-sa-web/tinig-ng-maralita/2658-the-poorscapegoat-for-the-greed-of-a-few-.html accessed 11 August 2012

Larrea C (2011) Inequality, sustainability and the greed line: a conceptual and empirical approach. The Ecumenical Review 63(4):263-277

Locke J (1690) Second treatise of government. Project Gutenberg. http://www.gutenberg.org/ebooks/7370 accessed 11 August 2012

Macpherson C B (1962) The political theory of possessive individualism. Oxford University Press, Oxford

Macy J and Brown M Y (1998) Coming back to life: practices to reconnect our lives, our world. New Society Publishers, Gabriola Island, BC, Canada

Medialens (no date) Media Lens home page. http://www.medialens.org accessed 11 August 2012

Murphy R (2011) The courageous state: rethinking economics, society and the role of government. Searching Finance, London

Pizzigati S (2004) Greed and good. Apex, Lanham, MD 
Raventós D (2007) Basic income: the material conditions of freedom. Pluto, London

Rifkin J (2000) The age of access: the new culture of hypercapitalism, where all of life is a paid-for experience. Tarcher/Putnam, New York

Roberts K (1982) Automation, unemployment and the distribution of income. European Centre for Work and Society, Maastricht

Robertson I (2012) The ultimate high. New Scientist 215(2872):28-29

Roland $\mathrm{J}$ (no date) Introduction to 'The moral equivalent of war' by William James. Constitution.org http://www.constitution.org/wj/meow_intro.htm accessed 11 August 201

Rosenberg M B (2005) Nonviolent communication: a language of life, 2nd edn. Puddledancer, Encinitas CA

Rowe D (1997) The real meaning of money. HarperCollins, London

Salter L (1962) The gramophone 40 (477):389-389 (also in http://en.wikiquote.org/wiki/Edgard_Var\%C3\%A8se accessed 11 August 2012)

Soanes C and Stevenson A (2003) Oxford dictionary of english, 2nd edn. Oxford University Press, Oxford

Vox P (2010) Sham democracy in Sweden.Vox Popoli. http://voxday.blogspot.co.uk/2010/09/somuch-for-democracy.html accessed 11 August 2012

Walter T (1989) Basic income: freedom from poverty, freedom to work. Marion Boyars, London ---END ---

[Author manuscript (postprint) of AI \& Society (2013) Vol 28, Issue 4, pp 531 - 539.

DOI 10.1007/s00146-012-0436-9 http://link.springer.com/article/10.1007/s00146-012-0436-9 ] 